\title{
Plasma proteomic profiles of healthy and mastitic cows - host responses to bovine mastitis
}

\author{
LiLi Niu, ${ }^{1,2}$, CaiHong Wei ${ }^{2}$ and LiXin Du² \\ ${ }^{1}$ College of Animal Science and Technology, Sichuan Agricultural University, Ya'an, China, ${ }^{2}$ Institute of Animal Science, \\ Chinese Academy of Agricultural Sciences, Beijing, China
}

\begin{abstract}
Mastitis is the most common disease in dairy cows and has resulted in a tremendous economic loss in dairy industry. In the present study, differentially expressed proteins (DEP) were identified among healthy, moderate and severe mastitic cows by proteomic profiling. The health status of cows was closely determined by the somatic cell count (SCC). Differentially expressed proteins were resolved using the two-dimensional gel electrophoresis (2-DE) with the $\mathrm{pH}$ 4-7 non-linear DryStrips. Subsequently, 8 protein spots, which altered more than 3-fold, were isolated and identified with the matrix-assisted laser desorption/ionisationtime of flight mass spectrometry (MALDI TOF/TOF MS). The identified spots were split into four proteins: a-2-HS-glycoprotein, serum albumin, transthyretin (TTR) and haptoglobin, respectively. Compared with the healthy cows, the expression of haptoglobin was upregulated in mastitic cows, and the others were down-regulated. Moreover, the proteomic data were consistent with the results of Western blot. All of the identified DEPs were acute phase proteins, which acted together and represented the consequence of serial cascades after mastitic infection. More importantly, the a-2-HS-glycoprotein was novel identified corresponding to the bovine mastitis in Chinese Holstein dairy cows. Taken together, our results indicate that the host responses may play an important role in the pathogenesis of mastitis and provide the potential diagnostic indicator of the underlying mastitis in dairy cows.
\end{abstract}

Keywords: bovine mastitis, DEP, host response, 2-DE 


\section{Introduction}

Mastitis is defined as an inflammation of the mammary gland that is usually caused by microbial infections and resulted in destruction of the milk secreting cells, which contributed to a permanent loss of productive ability consequently (Long et al. 2001). The bovine mastitis has a relatively high incidence worldwide and has been recognized as the most costly disease in the dairy industry (Huijps et al. 2008). It commonly occurs in response to intramammary bacterial infections, but also to intramammary mycoplasmal, fungal or algal infections. Depending on the duration of infection and appearance onset of clinical symptoms, mastitis could be assigned to clinical and subclinical bovine mastitis.

Somatic cell count (SCC) is one of the main indicators of milk quality, and also considered as a trait for mastitis resistance. In one individual, the SCC of $100 \times 10^{3} \mathrm{cell} / \mathrm{s} / \mathrm{mL}$ or less indicated an 'uninfected' cow, and there are no significant production losses. General agreement on the threshold SCC of $200 \times 10^{3}$ would determine whether a cow is infected with mastitis. Cows infected with mastitis have an $\mathrm{SCC}$ of $300 \times 10^{3}$ or greater. Meantime, the California Mastitis Test (CMT) is a simple cow-side indicator of the somatic cell count of milk. It disrupted the cell membrane of any cells present in the milk sample, allowing the DNA in those cells to react with the test reagent, forming a gel (Whyte et al. 2005). Somatic cell count and CMT were implemented in the routine stock evaluation in many countries. Many QTLs affecting SCC had been identified in the telomeric regions of BTA18 (Kühn et al. 2003, Xu et al. 2006, Kühn et al. 2008, Thomsen et al. 2011). Furthermore, a genome-wide significant QTL for clinical mastitis was detected (Schulman et al. 2004).

In this study, global views of the DEPs corresponding with healthy, moderate and severe mastitis were profiled by 2-DE. The identical spots with altered dosages which were expected to be relative to bovine mastitis were further identified by MALDI TOF/TOF MS and validated by western blot. Ultimately, the proteomic information in the plasma will highlight the pathophysiology of bovine mastitis and be helpful to identify potential targets for mastitis diagnosis and therapies.

\section{Material and methods}

\section{Plasma isolation and protein preparation}

Mammary quarter foremilk samples were tested using CMT and SCC A total of 20 Holstein dairy cows were selected for study [10 healthy cows (CMT negative, $\left.\mathrm{SCC} \leq 200 \times 10^{3}\right), 5$ moderate mastitic cows (CMT positive, $\mathrm{SCC}<2000 \times 10^{3}$ ) and 5 severe mastitic cows (CMT positive, $\left.\left.\mathrm{SCC}>2000 \times 10^{3}\right)\right]$. Blood samples were acquired by jugular venipuncture in $6 \mathrm{~mL}$ $\mathrm{K}_{2}$ EDTA Vacuum Blood Collection Tubes (BD Diagnostics, USA). Blood plasma was obtained by horizontal centrifugation at $1000 \times \mathrm{g}$ for $10 \mathrm{~min}$ at $4^{\circ} \mathrm{C}$. Then plasma was pooled with equivalent volume according to healthy, moderate and severe mastitic cows, separately. The supernatant phase was collected with pooled plasma centrifugation at $2400 \times \mathrm{g}$ for $15 \mathrm{~min}$ and aliquot stored in liquid nitrogen. 
Two-dimensional electrophoresis (2-DE)

Isoelectric focusing (IEF) was performed using $17 \mathrm{~cm}$, nonlinear, pH 4-7 DryStrips (Bio-Rad Laboratories Inc., Hercules, CA). Five $\mu \mathrm{L}$ of plasma with $10 \mu \mathrm{L}$ of $10 \%$ sodium dodecyl sulphate (SDS) and $2.3 \%$ dithiothreitol (DTT) were heated at $95^{\circ} \mathrm{C}$ for 5 min. DryStrips were rehydrated in $400 \mu \mathrm{L}$ of the rehydration buffer with $4 \mu \mathrm{L}$ of the treated sample (Alonso-Faust et al. 2012). Gels were stained using the silver staining method (Sinha et al. 2001). All gels were scanned using Powerlook 2100XL (UMAX Technologies, Inc., Taiwan).

\section{Image analysis}

The images of 2-DE gels were measured by the PDQuest software version 7.1 (Bio-Rad Laboratories). Three repetitive gels from each type of pooled plasma were analysed as one match-set to generate the master gel. Relative intensity of each matched spot on the master gel was compared with those from the healthy, moderate and severe mastitic cows. The protein spots with a 3-fold altered expression were cut, extracted and identified according to the well-established protocol (Yan et al. 2006).

\section{Western blot detection}

In an attempt to validate the proteomic results, western blot was performed with the specific antibodies for alpha-2-HS-glycoprotein, haptoglobin and TTR, respectively. After CMT and SCC test, one healthy $\left(S C C=200 \times 10^{3}\right)$ and two mastitic cows $\left(S C C=5985 \times 10^{3}\right.$ and $\left.1325 \times 10^{3}\right)$ were analysed. Total plasma protein concentration was precisely determined by the DC protein assay kit using gamma globulin as a standard (500-0111, Bio-Rad, Richmond, CA). One $\mu \mathrm{L}$ plasma sample (diluted 1:4) with $9 \mu \mathrm{L}$ loading buffer $(600 \mathrm{mM} \mathrm{pH} 6.8$ Tris-Hcl, $10 \%$ SDS, $50 \%$ sucrose, $10 \mathrm{mM} \mathrm{DTT}$ ) heated for $5 \mathrm{~min}$, was separated by $12 \%$ SDS/PAGE and then transferred to $0.45 \mu \mathrm{m}$ polyvinylidene fluoride membranes (Millipore, Bedford, MA) at $100 \mathrm{~V}$ for $1 \mathrm{~h}$ with cooling. The membranes were treated with antibody followed by washing with PBS-T and exposuring with ECL mixture. Film was scanned and the density of the protein band was quantified by Quantity One software (Bio-Rad, Laboratories).

\section{Results}

Two-dimensional proteome maps of bovine plasma

In our study, 173-233 distinct spots were detected with a molecular mass ranging from 100 $\mathrm{kDa}$ to $20 \mathrm{kDa}$ and with the $\mathrm{pH}$ scale from 4 to 7 . The representative plasma 2-DE profiles of plasma proteins were shown in Figure 1. There were 173 matched spots corresponding to healthy, moderate and severe mastitic cows, representing the $80.6 \%$ identical spots in the 2-DE gels. These protein spots were remained for further analyses.

\section{Identification of differentially expressed proteins}

Densitometry comparison of protein spots among healthy, moderate and severe mastitic cows were analysed with PDQuest 7.1 (Bio-Rad, Hercules, CA, USA), overlapped spots were not recognized. The expressions of 8 spots were altered more than 3 -fold whereat 6 protein 

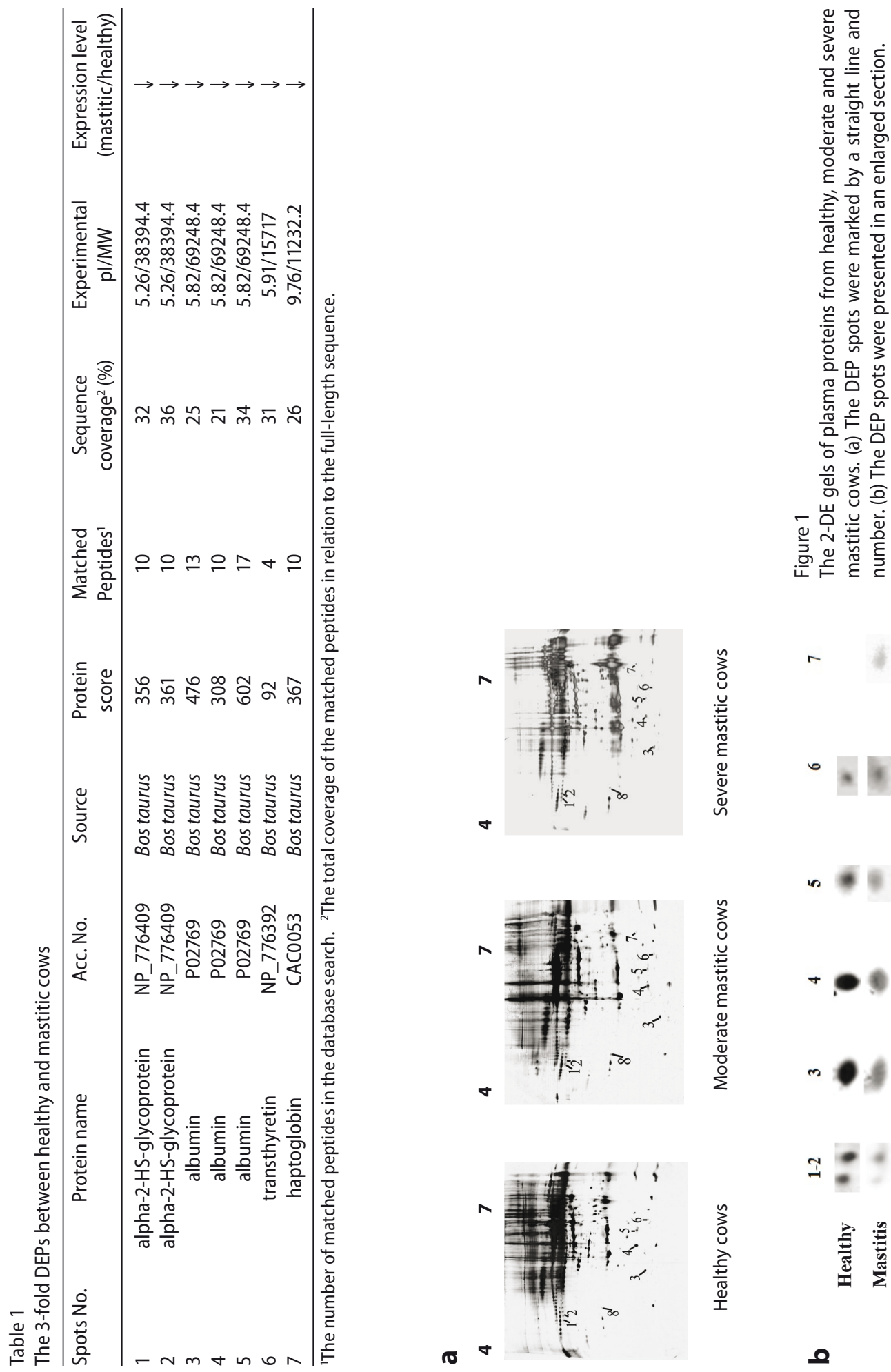

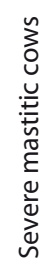

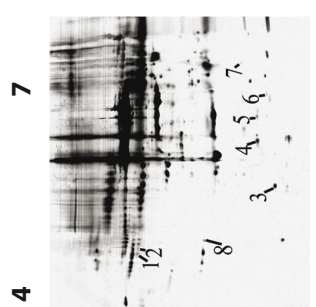

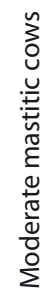

๑

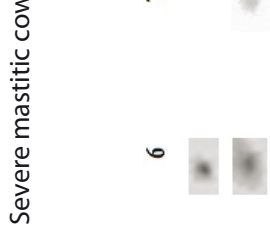

$\backsim$

(2)
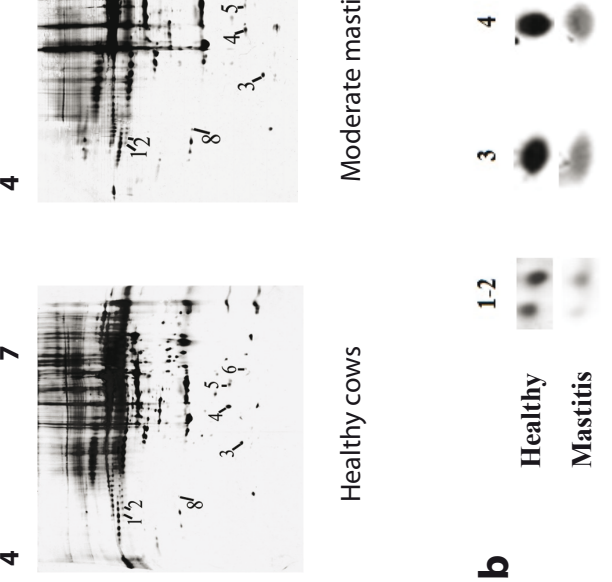

בิ

党 
spots showed a down-regulation and 2 protein spots displayed an over-expression in both moderate and severe mastitic cows. After MALDI-TOF/TOF MS, 6 protein spots (Spots 1-6) corresponded to 3 proteins: fetuin, TTR and serum albumin were identified, while the overexpressed spot (Spot 7) was haptoglobin (Table 1). Spot 8 was failed to be identified.

\section{Western blot analysis}

Fetuin and TTR were detectable at the $59 \mathrm{kDa}$ and $43 \mathrm{kDa}$ immunoreactive bands, respectively. The expression of fetuin was down-regulated in health cows, which was approximately 2-times lower than that in both moderate and severe mastitic cows. Transthyretin was also down-regulated in mastitic cows. Compared to the healthy group, the haptoglobin was detectable as one over $120 \mathrm{kDa}$ immunoreactive band and showed marginally significant 1.72- and 1.43-fold increases in moderate and severe mastitic groups, respectively (Figure 2).

a

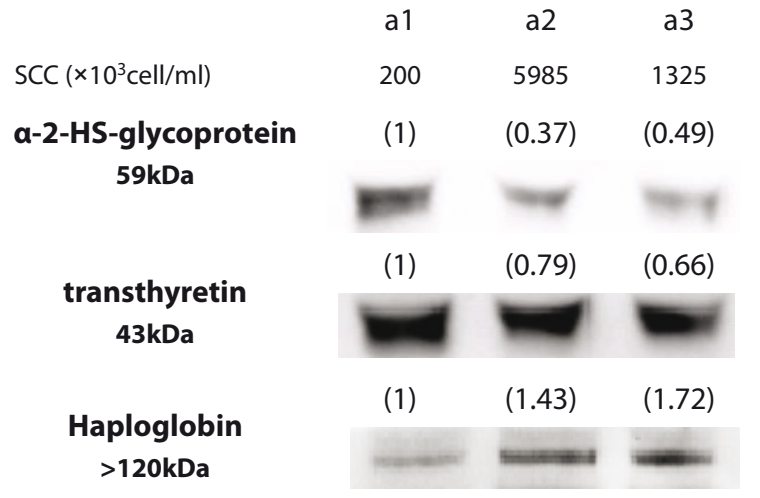

b Control

a1 a2 a3

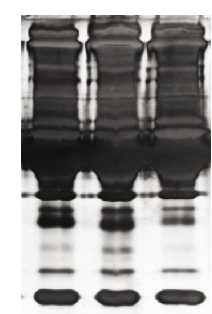

\section{Figure 2}

The DEPs was validated by western blot. (a) The representative image of DEPs. The values in parenthesis are the relative normalized intensities compared to those in healthy cows. (b) The internal control was indicated by the 2 -DE gels using $1 \mu \mathrm{L}$ total plasma protein.

\section{Discussion}

Protein down-regulated in the plasma of mastitic cows

Spots 1 and 2, alpha-2-Heremans-Schmid Glycoprotein

a-2-HS-glycoprotein, also called fetuin, is a secreted plasma protein that is expressed in hepatocytes, monocyte/macrophages and bone. Fetuin influenced the resolution of inflammation through enhancing the phagocytosis in foreign particles and apoptotic cells by macrophages (Wang et al. 1998, Jersmann et al. 2003), suggesting a positive role in the recovery phase of acute inflammatory responses (Lord et al. 2003). The hepatic mRNA levels of fetuin in human and rat transiently fell during the acute phase of a systemic inflammation (Ruminy et al. 2001). 
Spots 3 to 5 , serum albumin

Serum albumin was a negative acute-phase protein, with antioxidant function (Roche et al. 2008). The concentration of serum albumin increased due to increased capillary permeability in infected quarter milk (Nicholson et al. 2000). Rezamand et al. (2007) found that Holstein and Jersey dairy cows had greater albumin concentrations than animals with extra intramammary infection (IMI). The mean albumin concentration in blood decreased significantly during the acute-phase period by radial immunodiffusion, and the lowest level was found in Holstein-Friesian heifers infected with Escherichia coli after $12 \mathrm{~h}$ (Van Merris et al. 2004). However, the level of serum albumin was not altered in blood of Finnish Ayshire cows with Escherichia coli mastitis under the same protocols (Raulo et al. 2002).

\section{Spot 6, transthyretin (TTR or prealbumin)}

Transthyretin was related to the transport of thyroid hormones and retinol, which was affected by inflammation and malnutrition (Myron et al. 2007). It also was an inhibitor of monocyte and endothelial cell IL-1 production, thus, presenting anti-inflammatory properties (Borish et al. 1992). During inflammation status, the altered level of TTR was proposed to be a result of the change of some small molecules binding to endocrine proteins (Bernstein 2009). The concentrations of TTR and plasma retinol binding protein (RBP) were related to the infection rate of M. paratuberculosis in cattle (Seth et al. 2009).In Holstein and Jersey dairy cows with extra IMI, the plasma concentrations of TTR at week 1 postpartum were lower than those in cows without IMI (Rezamand et al. 2007).

\section{Protein up-regulated in the plasma of mastitic cows}

Spot 7, haptoglobin

Haptoglobin was a haemoglobin binding protein and also played an anti-inflammatory role (Quaye 2008). Haptoglobin had been reported to be a useful indicator of bovine bacterial infection. It also was synthesized in mammary gland (Thielen et al. 2007), and its concentration increased 200-fold locally in infected quarters (Mitterhuemer et al. 2010), which started to rise $24 \mathrm{~h}$ after E. coli inoculation and peaked at 60-68 hours (Suojala et al. 2008). Chronic purulent infections continuously induced the production of haptoglobin, whereas short-lived coliform infections might only trigger a temporary haptoglobin response (Petersen et al. 2004).

\section{Potential novel indicator for mastitis}

The a-2-HS-glycoproteinwas identified previously in 2-DE of mastitis whey and milk, which accounted for the leakage of serum proteins (Anderson et al. 2002, Smolenski et al. 2007). However, the identification of a-2-HS-glycoprotein in blood plasma has not been reported yet in mastitic cows. In our study, the level of a-2-HS-glycoprotein in plasma was related to the morbidity of mastitis and verified by western blot. Thus, we suggest that a-2-HS-glycoprotein based screening test may be used to monitor progression of the bovine mastitis.

In conclusion, in the study, all of the DEPs were acute phase proteins. Their altered expressions in plasma revealed the host defence to inflammation. To minimize the damage of mammary tissue caused by bacterial toxins and reactive oxygen species released from neutrophils, inflammatory response needs to be regulated by systemic factors (Burvenich et 
al. 2007, Paap et al. 2002). It had been reported that the host defence status was a cardinal factor determining the outcome of the disease in E. coli mastitis (Burvenich et al. 2003). Our data will highlight the pathophysiology of bovine mastitis and be helpful to identify potential targets for mastitis diagnosis in future.

\section{References}

Anderson NL, Anderson NG (2002) The Human Plasma Proteome History, Character, and Diagnostic Prospects. MCP 1, 845-867

Bernstein LH (2009) Transthyretin and the Systemic Inflammatory Response. Curr Nutr Food Sci 5, 71-74

Borish L, King MS, Mascali JJ, Johnson S, Coll B, Rosenwasser LJ (1992) Transthyretin is an inhibitor of monocyte and endothelial cell interleukin-1 production. Inflammation 16, 471-484

Burvenich C, Van Merris V, Mehrzad J, Diez-Fraile A, Duchateau L (2003) Severity of E. coli mastitis is mainly determined by cow factors. Vet Res 34, 521-564

Huijps K, Lam TJGM, Hogeveen H (2008) Costs of mastitis: facts and perception. J Dairy Res 75, 113-120

Jersmann HPA, Dransfield I, Hart SP (2003) Fetuin/a2-HS glycoprotein enhances phagocytosis of apoptotic cells and macropinocytosis by human macrophages. Clin Sci (Lond) 105, 273-278

Kühn C, Bennewitz J, Reinsch N, Xu N, Thomsen H, Looft C, Brockmann GA, Schwerin M, Weimann C, Hiendleder S, Erhardt G, Medjugorac I, Förster M, Brenig B, Reinhardt F, Reents R, Russ I, Averdunk G, Blümel J, Kalm E (2003) Quantitative Trait Loci Mapping of Functional Traits in the German Holstein Cattle Population. J Dairy Sci 86, 360-368

Kühn C, Reinhardt F, Schwerin M (2008) Marker assisted selection of heifers improved milk somatic cell count compared to selection on conventional pedigree breeding values. Arch Tierz 51, 23-32

Long E, Capuco AV, Wood DL, Sonstegard T, Tomita G, Paape MJ, Zhao X (2001) Escherichia coli induces apoptosis and proliferation of mammary cells. Cell Death Differ 8, 808-816

Lord JM (2003) A physiological role for a2-HS glycoprotein: stimulation of macrophage uptake of apoptotic cells. Clin Sci (Lond) 105, 267-268

Mitterhuemer S, Petzl W, Krebs S, Mehne D, Klanner A, Wolf E, Zerbe H, Blum H (2010) Escherichia coli infection induces distinct local and systemic transcriptome responses in the mammary gland. BMC Genomics 11, 138

Myron Johnson A, Merlini G, Sheldon J, Ichihara K (2007) Clinical indications for plasma protein assays: transthyretin (prealbumin) in inflammation and malnutrition. CCLM/FESCC 45, 419-426

Nicholson JP, Wolmarans MR, Park GR (2000) The role of albumin in critical illness. Br J Anaesth 85, 599-610

Paape M, Mehrzad J, Zhao X, Detilleux J, Burvenich C (2002) Defense of the Bovine Mammary Gland by Polymorphonuclear Neutrophil Leukocytes. J Mammary Gland Biol Neoplasia 7, 109-121

Petersen HH, Nielsen JP, Heegaard PMH (2004) Application of acute phase protein measurements in veterinary clinical chemistry. Vet Res 35, 163-187

Quaye IK (2008) Haptoglobin, inflammation and disease. Trans R Soc Trop Med Hyg 102, 735-742

Raulo SM, Sorsa T, Tervahartiala T, Latvanen T, Pirilä E, Hirvonen J, Maisi P (2002) Increase in milk metalloproteinase activity and vascular permeability in bovine endotoxin-induced and naturally occurring Escherichia coli mastitis. Vet Immunol Immunopathol 85, 137-145

Rezamand P, Hoagland TA, Moyes KM, Silbart LK, Andrew SM (2007) Energy Status, Lipid-Soluble Vitamins, and Acute Phase Proteins in Periparturient Holstein and Jersey Dairy Cows With or Without Subclinical Mastitis. J Dairy Sci 90, 5097-5107

Roche M, Rondeau P, Singh NR, Tarnus E, Bourdon E (2008) The antioxidant properties of serum albumin. FEBS Lett 582, 1783-1787 
Ruminy P, Gangneux C, Claeyssens S, Scotte M, Daveau M, Salier JP (2001) Gene transcription in hepatocytes during the acute phase of a systemic inflammation: from transcription factors to target genes. Inflamm Res 50, 383-390

Schulman NF, Viitala SM, de Koning DJ, Virta J, Mäki-Tanila A, Vilkki JH (2004) Quantitative Trait Loci for Health Traits in Finnish Ayrshire Cattle. J Dairy Sci 87, 443-449

Seth M, Lamont EA, Janagama HK, Widdel A, Vulchanova L, Stabel JR, Waters WR, Palmer MV, Sreevatsan S (2009) Biomarker Discovery in Subclinical Mycobacterial Infections of Cattle. PLoS One 4, e5478

Sinha P, Poland J, Schnölzer M, Rabilloud T (2001) A new silver staining apparatus and procedure for matrix-assisted laser desorption/ionization-time of flight analysis of proteins after two-dimensional electrophoresis. Proteomics 1, 835-840

Smolenski G, Haines S, Kwan FYS, Bond J, Farr V, Davis SR, Stelwagen K, Wheeler TT (2007) Characterisation of Host Defence Proteins in Milk Using a Proteomic Approach. J Proteome Res 6, 207-215

Suojala L, Orro T, Järvinen H, Saatsi J, Pyörälä S (2008) Acute phase response in two consecutive experimentally induced E. coli intramammary infections in dairy cows. Acta Vet Scand 50, 18

Thielen MA, Mielenz M, Hiss S, Zerbe H, Petzl W, Schuberth HJ, Seyfert HM, Sauerwein H (2007) Short communication: Cellular Localization of Haptoglobin mRNA in the Experimentally Infected Bovine Mammary Gland. J Dairy Sci 90, 1215-1219

Thomsen H, Thomasen JR, Guldbrandtsen B, Lund MS (2011) QTL explaining variation in production traits and udder health in the Danish Holstein population. Arch Tierz 54, 348-359

Van Merris V, Meyer E, Duchateau L, Blum J, Burvenich C (2004) All-trans Retinoic Acid Is Increased in the Acute Phase-Related Hyporetinemia During Escherichia coli Mastitis. J Dairy Sci 87, 980-987

Wang H, Zhang M, Bianchi M, Sherry B, Sama A, Tracey KJ (1998) Fetuin (a2-HS-glycoprotein) opsonizes cationic macrophage- deactivating molecules. Proc Natl Acad Sci U S A 95, 14429-14434

Whyte D, Walmsley M, Liew A, Claycomb R, Mein G (2005) Chemical and rheological aspects of gel formation in the California Mastitis Test. J Dairy Res 72, 115-121

Xu NG, Paul S, Bennewitz J, Reinsch N, Thaller G, Reinhardt F, Kühn C, Schwerin M, Erhardt G, Weimann C, Thomsen H, Mishra S, Kalm E (2006) Confirmation of quantitative trait loci for somatic cell score on bovine chromosome 18 in the German Holstein. Arch Tierz 49, 111-119

Yan SP, Zhang QY, Tang ZC, Su WA, Sun WN (2006) Comparative Proteomic Analysis Provides New Insights into Chilling Stress Responses in Rice. Mol Cell Proteomics 5, 484-496 